\title{
Receptor Subtypes Involved in the Presynaptic and Postsynaptic Actions of Dopamine on Striatal Interneurons
}

\author{
Diego Centonze, ${ }^{1}$ Cristina Grande, ${ }^{2}$ Alessandro Usiello, ${ }^{3}$ Paolo Gubellini, ${ }^{1}$ Eric Erbs, ${ }^{3}$ Ana B. Martín, ${ }^{2}$ Antonio Pisani, ${ }^{1}$ \\ Nadia Tognazzi, ${ }^{3}$ Giorgio Bernardi, ${ }^{1}$ Rosario Moratalla, ${ }^{2 \star}$ Emiliana Borrelli, ${ }^{3 \star}$ and Paolo Calabresi ${ }^{1 \star}$ \\ ${ }^{1}$ Clinica Neurologica, Dipartimento di Neuroscienze, Università “Tor Vergata," 00133 Rome, Italy, and Istituto di Ricovero e Cura a Carattere Scientifico \\ Fondazione Santa Lucia, 00179 Rome, Italy, ${ }^{2}$ Instituto Cajal, Consejo Superior de Investigaciones Científicas, 28002 Madrid, Spain, and ${ }^{3}$ Institut de \\ Génétique et de Biologie Moléculaire et Cellulaire, Centre National de la Recherche Scientifique-Institut National de la Santé et de la Recherche Médicale- \\ Université Louis Pasteur, BP 10142, CU de Strasbourg, France
}

By stimulating distinct receptor subtypes, dopamine (DA) exerts presynaptic and postsynaptic actions on both large aspiny (LA) cholinergic and fast-spiking (FS) parvalbumin-positive interneurons of the striatum. Lack of receptor- and isoform-specific pharmacological agents, however, has hampered the progress toward a detailed identification of the specific DA receptors involved in these actions.

To overcome this issue, in the present study we used four different mutant mice in which the expression of specific DA receptors was ablated. In D1 receptor null mice, D1R - /-, DA dose-dependently depolarized both LA and FS interneurons. Interestingly, SCH 233390 $(10 \mu \mathrm{M})$, a D1-like (D1 and D5) receptor antagonist, but not L-sulpiride (3-10 $\mu \mathrm{M})$, a D2-like (D2, D3, D4) receptor blocker, prevented this effect, implying D5 receptors in this action. Accordingly, immunohistochemical analyses in both wild-type and D1R - I- mice confirmed the expression of $\mathrm{D} 5$ receptors in both cholinergic and parvalbumin-positive interneurons of the striatum.

In mice lacking D2 receptors, D2R-/-, the DA-dependent inhibition of GABA transmission was lost in both interneuron populations. Both isoforms of D2 receptor, D2L and D2S, were very likely involved in this inhibitory action, as revealed by the electrophysiological analysis of the effect of the DA D2-like receptor agonist quinpirole in two distinct mutants lacking D2L receptors and expressing variable contents of $\mathrm{D} 2 \mathrm{~S}$ receptors.

The identification of the receptor subtypes involved in the actions of DA on different populations of striatal cells is essential to understand the circuitry of the basal ganglia and to develop pharmacological strategies able to interfere selectively with specific neuronal functions.

Key words: basal ganglia; D1 receptors; D2L receptors; D2S receptors; electrophysiology; GABA transmission; mutant mice

\section{Introduction}

Nigrostriatal dopamine (DA) innervation plays an essential role in the control of striatal neuron activity by interacting with multiple membrane conductances (Calabresi et al., 1987; Schiffmann et al., 1995; Surmeier et al., 1995; Lin et al., 1996; HernandezLopez et al., 2000) and with excitatory and inhibitory transmission (Cepeda et al., 1993, 1998, 2001; Hsu et al., 1995; Delgado et al., 2000; Flores-Hernandez et al., 2000; Centonze et al., 2002). In

\footnotetext{
Received Dec. 16, 2002; revised April 24, 2003; accepted April 24, 2003.

This work was supported by grants from Institut National de la Santé et de la Recherche Médicale, Centre National de la Recherche Scientifique, Hopitaux Universitaires de Strasbourg, and Mission Inteministérielle de Lutte contre la Drogue et la Toxicomanie (E.B.); from Spanish Ministerio de Ciencia y Tecnología SAF200-0122, Plan National Sobre Drogas and Fundación La Caixa, Spain (R.M.); and from Consiglio Nazionale delle Ricerche and Ministero della Salute, Progetto Finalizzato Schizofrenia (P.C.).

${ }^{*}$ R.M., E.B., and P.C. contributed equally to this work.

Correspondence should be addressed to one of the following: Paolo Calabresi, Clinica Neurologica, Dipartimento di Neuroscienze, Università di Roma "Tor Vergata," Via Montpellier 1, 00133 Rome, Italy, E-mail: paolo.calabresi@uniroma2.it; or Rosario Moratalla, Instituto Cajal, Consejo Superior de Investigaciones Científicas, Avenida Dr. Arce 37, 28002, Madrid, Spain, E-mail: moratalla@cajal.csic.es; or Emiliana Borrelli, Institut de Génétique et de Biologie Moléculaire et Cellulaire, Centre National de la Recherche Scientifique-Institut National de la Santé et de la Recherche Médicale-ULP1, Rue L. Fries, BP10142, 67404 Illkirch Cedex, C.U. de Strasbourg, France, E-mail: eb@titus.u-strasbg.fr.

Copyright $\odot 2003$ Society for Neuroscience $\quad 0270-6474 / 03 / 236245-10 \$ 15.00 / 0$
}

addition, DA exerts a complex modulatory control on the activity of striatal projection neurons through long-term mechanisms (Calabresi et al., 1997, 2000b; Arbuthnott et al., 2000; Centonze et al., 2001; Kerr and Wickens, 2001; Tang et al., 2001). In recent years, the modulation of interneuron activity has emerged as a critical function of DA in the striatum (Yan and Surmeier, 1997; Yan et al., 1997; Aosaki et al., 1998; Pisani et al., 2000; Momiyama and Koga, 2001; Bracci et al., 2002). The DA-mediated regulation of striatal interneuron activity, in turn, may provide strong control of the whole basal ganglia circuitry.

On the basis of the main transmitter released, striatal interneurons are differentiated into two distinct groups: cholinergic cells and GABAergic cells. They comprise only $2-4 \%$ of the neuronal population of the striatum, the remaining being represented by medium spiny projection cells (Kawaguchi, 1992, 1993; Kawaguchi et al., 1995). Striatal cholinergic interneurons are large $(20-50 \mu \mathrm{m})$ aspiny neurons and represent the main source of acetylcholine (Ach) in the striatum. These neurons modulate spiny neuron activity through presynaptic and postsynaptic actions (Galarraga et al., 1999; Calabresi et al., 2000a; Koos and Tepper, 2002). On the other hand, GABAergic interneurons are aspiny cells of medium size $(10-25 \mu \mathrm{m})$ that are immunoreactive 
for parvalbumin or nitric oxide synthase and provide a strong inhibitory control of striatal output neurons through monosynaptic IPSPs (Plenz and Kitai, 1998; Koos and Tepper, 1999).

DA controls striatal interneuron activity via presynaptic and postsynaptic actions and distinct receptor subtypes. Pharmacological studies in slices have revealed that DA receptors of the D1-like subfamily (D1 or D5 receptors) are involved mainly in the direct membrane depolarization of both large aspiny (LA) cholinergic cells (Aosaki et al., 1998; Pisani et al., 2000) and fastspiking (FS) GABAergic interneurons (Bracci et al., 2002). Conversely, activation of receptors of the D2-like subfamily (D2, D3, or $\mathrm{D} 4$ receptors) causes, through a presynaptic action, the inhibition of $\mathrm{GABA}_{\mathrm{A}}$-mediated synaptic inputs to both intrinsic striatal cell types (Pisani et al., 2000; Momiyama and Koga, 2001; Bracci et al., 2002). So far, however, the lack of receptor-specific pharmacological agents has hampered the progress toward a more detailed identification of the DA receptors involved in the modulatory actions of DA on these interneurons.

In the present in vitro electrophysiological studies, we used four different mutant mice, in which the expression of specific DA receptors is either ablated or altered to clarify the involvement of the most abundant DA receptors expressed in the striatum, D1 and D2, in these functions. To do this, D1 and D2 receptor-deficient mice were used to identify the receptor subtype involved in the depolarizing and presynaptic effects, respectively, of DA on both LA and FS interneurons. In addition, to detail which receptor isoform of the D2 receptor mediates the inhibitory action of DA on the GABAergic inputs to these cells, we used two recently generated mice. These mice are characterized by the complete absence of the long isoform of the D2 receptors (D2L) but by variable expression of the D2S isoform.

\section{Materials and Methods}

Male mice lacking DA D1 (D1R-/-) (Xu et al., 1994), D2 (D2R-/-) (Baik et al., 1995), and D2L (Usiello et al., 2000) receptors were used, along with their wild-type (WT) counterparts (2-3 months old), for all of the electrophysiological experiments. Two distinct genotypes of D2Llacking mice were used. Ablation of D2L receptors (D2L-/-) results in a conversion of the totality of the D2R transcripts into D2S receptors. This leads to overexpression of the D2S receptors (Usiello et al., 2000) as compared with its level in WT littermates. We thus also generated $\mathrm{D} 2 \mathrm{~L}-1-$ animals with a lower number of $\mathrm{D} 2 \mathrm{~S}$ sites by mating $\mathrm{D} 2 \mathrm{R}-1-$ mice with $\mathrm{D} 2 \mathrm{~L}-/-$ mice. In these mice, the complete absence of $\mathrm{D} 2 \mathrm{~L}$ receptors is coupled with a closer to normal expression of $\mathrm{D} 2 \mathrm{~S}$ receptors (D2R-/-;D2L-/-) (see Results). The D2R ligand binding assays on striatal membranes were performed as described previously (Baik et al., 1995). Briefly, striata were homogenized with a polytron in ice-cold buffer containing $10 \mathrm{~mm}$ Tris- $\mathrm{HCl}, \mathrm{pH} 7.5$, and $5 \mathrm{~mm}$ EDTA. The homogenates were centrifuged at $19,000 \times g$ for $40 \mathrm{~min}$ at $4^{\circ} \mathrm{C}$ and then the supernatants were collected and centrifuged again. Ligand-binding assays were performed with $15 \mu \mathrm{g}$ of striatal membranes using $\left[{ }^{3} \mathrm{H}\right]$ spiperone (specific activity $84 \mathrm{Ci} \mathrm{mmol}$; Amersham Biosciences, Piscataway, $\mathrm{NJ})$ at concentrations of 0.01-0.6 nM; nonspecific binding was determined in the presence of $1 \mu \mathrm{M}(+)$-butaclamol. Binding data were analyzed with the GraphPad Prism program. Experiments were performed three times in triplicate.

\section{Electrophysiology}

Corticostriatal coronal slices $(200-300 \mu \mathrm{m})$ were prepared from tissue blocks of the brain with the use of a vibratome (Calabresi et al., 1997, 2000b). A single slice was then transferred to a recording chamber and submerged in a continuously flowing Krebs' solution $\left(35^{\circ} \mathrm{C}, 2-3 \mathrm{ml} / \mathrm{min}\right)$ gassed with $95 \% \mathrm{O}_{2} / 5 \% \mathrm{CO}_{2}$. The composition of the control solution was (in mM): $126 \mathrm{NaCl}, 2.5 \mathrm{KCl}, 1.2 \mathrm{MgCl}_{2}, 1.2 \mathrm{NaH}_{2} \mathrm{PO}_{4}, 2.4 \mathrm{CaCl}_{2}, 11$ glucose, $25 \mathrm{NaHCO}_{3}$.

Whole-cell patch-clamp recordings were made with borosilicate glass pipettes ( $1.8 \mathrm{~mm}$ outer diameter; $3-5 \mathrm{M} \Omega$ ) containing (in $\mathrm{mM}$ ): 125 $\mathrm{K}^{+}$-gluconate, $10 \mathrm{NaCl}, 1.0 \mathrm{CaCl}_{2}, 2.0 \mathrm{MgCl}_{2}, 0.5$ BAPTA, 19 HEPES, $0.3,1.0 \mathrm{Mg}$-ATP, adjusted to $\mathrm{pH} 7.3$ with $\mathrm{KOH}$.

The striatum could be readily identified under low-power magnification, whereas individual neurons were visualized in situ using a differential interference contrast (Nomarski) optical system. This used an Olympus BX50WI (Tokyo, Japan) noninverted microscope with $40 \times$ water immersion objective combined with an infrared filter, a monochrome CCD camera (COHU 4912), and a PC-compatible system for analysis of images and contrast enhancement (WinVision 2000, Delta Sistemi, Rome, Italy). Recording pipettes were advanced toward individual cells in the slice under positive pressure, and on contact, tight $\mathrm{G} \Omega$ seals were made by applying negative pressure. The membrane patch was then ruptured by suction, and membrane current and potential were monitored using an Axopatch 1D patch-clamp amplifier (Axon Instruments, Foster City, CA). Whole-cell access resistances measured in voltage clamp were in the range of 5-30 M $\Omega$ before electronic compensation (60-80\% was used routinely). For synaptic stimulation, bipolar electrodes were used. These stimulating electrodes were located within the striatum close to the recording electrode. $\mathrm{GABA}_{\mathrm{A}}$-mediated synaptic outward currents (IPSCs) were evoked at a frequency of $0.1 \mathrm{~Hz}$ and a holding potential of $0 \mathrm{mV}$. All of the experiments were performed in the presence of $(+)-\mathrm{MK}$ 801 maleate (MK-801; $30 \mu \mathrm{M})$ and 6-cyano-7-nitroquinoxaline-2,3dione (CNQX; $10 \mu \mathrm{M}$ ) to block, respectively, NMDA and AMPA glutamate receptors. Quantitative data on modifications of IPSCs are expressed as a percentage of the controls, the latter representing the mean of responses recorded during a stable period (5-10 $\mathrm{min})$ in control medium.

To study spontaneous $\mathrm{GABA}_{\mathrm{A}}$-mediated IPSCs, the recording pipettes (5-8 $\mathrm{M} \Omega$ ) were filled with internal solution of the following composition (in mM): $110 \mathrm{CsCl}, 30 \mathrm{~K}^{+}$-gluconate, $1.1 \mathrm{EGTA}, 10 \mathrm{HEPES}, 0.1 \mathrm{CaCl}_{2}, 4$

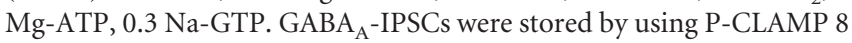
(Axon Instruments) and analyzed off-line on a personal computer with Mini Analysis 5.1 (Synaptosoft, Leonia, NJ) software. The detection threshold was set at twice the baseline noise. The fact that no false events would be identified was confirmed by visual inspection for each experiment. Off-line analysis was performed on IPSCs recorded during a fixed time epoch (3-5 $\mathrm{min}$ ), sampled every 5 or $10 \mathrm{~min}$ before (two samplings) and after (three to six samplings) the application of quinpirole. Only cells that exhibited a stable GABA $_{\mathrm{A}}$-IPSC frequency in control $(<20 \%$ changes during the two control samplings) were taken into account. Averaged cumulative histograms were obtained by normalizing each distribution to the corresponding maximal value obtained in control. For data presented as the mean \pm SEM, statistical analysis was performed using a paired or unpaired Student's $t$ test or Wilcoxon's test. When the differences between two cumulative distributions were compared, the Kolmogorov-Smirnov (K-S) test was used. The significance level was established at $p<0.05$.

Drugs were applied by dissolving them to the desired final concentration in saline. CNQX and MK-801 were from Tocris (Bristol, UK). Bicuculline, quinpirole, and SCH 23390 were from RBI (Natick, MA). DA, tetrodotoxin (TTX), and L-sulpiride were from Sigma (St. Louis, MO).

Animals and tissue preparation for immunoassays

Adult male D1R-/- and WT mice were deeply anesthetized with sodium pentobarbital and perfused intracardially with $4 \%$ paraformaldehyde in $0.1 \mathrm{~m}$ phosphate buffer (PB), $\mathrm{pH}$ 7.4. Their brains were removed and postfixed in the same solution for $2 \mathrm{hr}$ at $4^{\circ} \mathrm{C}$. Fixed brains were cryoprotected with $30 \%$ sucrose in $0.1 \mathrm{~m}$ PBS, frozen in dry ice and sectioned ( $25 \mu \mathrm{m}$ thick) with a freezing microtome. Coronal sections through the striatum were collected and stored in PBS with $0.02 \%$ sodium azide at $4^{\circ} \mathrm{C}$ for immunocytochemistry. All of the studies were approved by the appropriate animal care committee at the Cajal Institute, Consejo Superior de Investigaciones Científicas (CSIC), and all efforts were made to minimize the number of animals used and their suffering.

\section{Antisera information}

To localize DA D5 receptors, we used a polyclonal rabbit antiserum developed and characterized at the Cajal Institute, CSIC (see below). The 
dilution used was 1:2000. Striatal interneurons were identified with a polyclonal goat antiserum against choline acetyltransferase (ChAT; 1:1000 dilution; Chemicon, Temecula, CA) for cholinergic neurons and a monoclonal mouse antibody against parvalbumin (PV; 1:1000 dilution; Sigma). All primary antibodies were diluted in $0.1 \mathrm{M}$ PBS, with $0.2 \%$ Triton X-100 (PBS-TX), 1\% bovine serum albumin, and 0.1\% sodium azide.

Generation of a polyclonal antiserum against D5

dopamine receptor

A specific polyclonal antiserum against the mouse dopamine D5 receptor was raised at the Cajal Institute, CSIC.

Generation of a glutathione S-transferase-D5 receptor fusion protein. A fragment of cDNA encoding the $\mathrm{C}$ terminus of the mouse dopamine D5 receptor (amino acids 377-477) was generated by PCR using specific primers designed from the published sequence. The sequence of the forward primer was $5^{\prime}$-CGGGATCCGTGCAGACGGTAAACATC-3' and that of the reverse primer was $5^{\prime}$-GCGAATTCCTAACAGTTTTATGGAAAC- $3^{\prime}$. These primers incorporate BamHI and EcoRI sites at their $5^{\prime}$ ends, respectively, to ensure successful subcloning and fragment orientation. PCR reaction conditions were $94^{\circ} \mathrm{C}$ for $4 \mathrm{~min}, 55^{\circ} \mathrm{C}$ for 30 sec, and $72^{\circ} \mathrm{C}$ for $30 \mathrm{sec}$, followed by 25 cycles of $94^{\circ} \mathrm{C}$ for $30 \mathrm{sec}, 55^{\circ} \mathrm{C}$ for $30 \mathrm{sec}$, and $72^{\circ} \mathrm{C}$ for $30 \mathrm{sec}$. Then, the reaction product was incubated for 2 min at $72^{\circ} \mathrm{C}$ and quickly taken to $4^{\circ} \mathrm{C}$ in ice-chilled water. The PCR product was purified by GEN-CLEAN (Q-Biogen), digested with BamHI and EcoRI, and purified once again with GEN-CLEAN. The DNA fragment was ligated between the BamHI and EcoRI sites of the plasmid pGEX-2T for bacterial expression of a fusion protein composed of glutathione $S$-transferase (GST) and the C terminus of D5 receptor.

Generation of anti-D5 receptor antiserum. Bacterial expression of GST/D ${ }_{5}$ receptor was induced in exponentially growing Escherichia coli $B c l$ with $0.5 \mathrm{~mm}$ isopropyl- $\beta$-thiogalactopyranoside for $8 \mathrm{hr}$. The recombinant fusion protein was then purified using glutathione Sepharose 4B beads (Amersham Biosciences), and it was used subsequently to inoculate two rabbits following standard protocols. Serum samples were collected at different times after inoculation to monitor antibody production with an enzyme-linked immunosorbent assay.

Purification of anti-D5 receptor antiserum by high-affinity chromatography. We have used the immunospecific method that exploits the antigen-antiserum binding specificity. Purified GST-D5 fusion protein (8 $\mathrm{mg}$ ) was immobilized on $1 \mathrm{gm}$ of cianogen bromide-activated Sepharose resin (Amersham Biosciences) using a coupling buffer $\left(0.1 \mathrm{M} \mathrm{NaHCO}_{3} /\right.$ $0.5 \mathrm{M} \mathrm{NaCl}, \mathrm{pH}$ 8.3). Then, the resin was incubated in $0.2 \mathrm{M}$ glycine, $\mathrm{pH}$ 8.0 , to block the remaining active groups and rinsed three times with coupling buffer and distilled water. The resin was equilibrated with PBS buffer, and then $1 \mathrm{ml}$ of the anti-D5 antiserum (diluted 10 times in Tris- $\mathrm{HCl}$ buffer) was mixed and incubated with the beads for $4 \mathrm{hr}$. This sample was transferred into a Bio-Rad column (Bio-Rad, Hercules, CA), rinsed with $20 \mathrm{vol}$ of $10 \mathrm{~mm}$ Tris, $\mathrm{pH} 7.5$, and rinsed again with $10 \mathrm{vol}$ of $50 \mathrm{~mm}$ Tris and $100 \mathrm{~mm} \mathrm{NaCl}, \mathrm{pH}$ 7.5. After that, the antibody was eluted

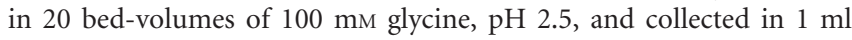
elution fractions. Antibody-containing fractions were pooled and dialyzed overnight in $0.1 \mathrm{M}$ PBS with $0.02 \%$ sodium azide. The specificity of the anti-D5 receptor antiserum was determined by immunohistochemistry and Western blot analysis.

\section{Immunoblot analysis}

Brains were removed rapidly from decapitated WT mice and rats. Prefrontal cortex and striatum were isolated and frozen immediately on dry ice. Brain samples were dounce-homogenized in $20 \mathrm{vol}$ of buffer containing 20 mм HEPES, pH 7.9, $0.4 \mathrm{M} \mathrm{NaCl}, 20 \%$ glycerol, 5 mм $\mathrm{MgCl}_{2}, 0.5$ mM EDTA, 0.1 mм EGTA, 1\% IGEPAL CA-630, $10 \mathrm{mg} / \mathrm{ml} \mathrm{leupeptin,} 0.1$ $\mathrm{mm} p$-aminobenzamidine, $1 \mathrm{mg} / \mathrm{ml}$ pepstatin, $0.5 \mathrm{~mm}$ phenylmethylsufonyl fluoride, and $5 \mathrm{~mm}$ dithiothreitol. Samples were incubated in this buffer for $30 \mathrm{~min}$ at $4^{\circ} \mathrm{C}$, and insoluble material was removed by centrifugation at $15,000 \times g$ for $30 \mathrm{~min}$. Protein concentration in resulting extracts was assayed using the Bio-Rad Bradford method.

Aliquots of protein extracts (containing $70 \mu \mathrm{g}$ of protein) were boiled for $3 \mathrm{~min}$ and separated by size on a minigel SDS-PAGE apparatus (Bio-
Table 1. Combination of antisera used in each double-immunolabeling reaction

\begin{tabular}{lll}
\hline Staining & Primary antibodies & Secondary antibodies \\
\hline D5/ChAT & Rabbit anti-D5 & Alexa 598-conjugated chicken anti-rabbit (red) \\
& Goat anti-ChAT & Alexa 488-conjugated chicken anti-goat (green) \\
D5/PV & Rabbit anti-D5 & Alexa 598-conjugated goat anti-rabbit (red) \\
& Mouse anti-PV & CY2 goat anti-rat (green) \\
\hline
\end{tabular}

Alexa-conjugated secondary antibodies were supplied by Molecular Probes (Eugene, OR), and the cyanineconjugated secondary antibody was supplied by Amersham Biosciences. ChAT, Choline acetyltransferase; PV, parvalbumin.

Rad) using $10 \%$ polyacrylamide gel (with a 29:1 ratio of acrylamide to $N, N^{\prime}$-methylenebisacrylamide). Proteins were transferred electrophoretically to a nitrocellulose membrane (Schleicher \& Schuell, Dassel, Germany). Blots were incubated with antiserum at 1:1000 dilution in buffer containing $5 \%$ nonfat dairy milk for $4 \mathrm{hr}$. Goat anti-rabbit IgG conjugated to horseradish peroxidase was used to detect the binding of anti-D5 antibody. The immunoreactive bands were detected autoradiographically using Hyperfilm-enhanced chemiluminescence (ECL) films (Amersham Biosciences) and an ECL kit (Amersham Biosciences). Molecular weights were determined on the basis of the mobility of prestained SDS-PAGE standards, broad range (Bio-Rad).

\section{Immunohistochemical procedures}

Free-floating double-labeled immunocytochemistry was performed in brain sections from WT and D1R-/- mice following Rivera et al. (2002a). Nonspecific binding sites in tissue sections were blocked with $5 \%$ bovine serum albumin in PBS-TX for $30 \mathrm{~min}$. Sections were washed in PBS and incubated with anti-D5 antiserum and anti-ChAT antiserum or anti-PV during $48 \mathrm{hr}$ at $4^{\circ} \mathrm{C}$. The distribution of the antibodies was detected using the appropriate fluorescence-conjugated secondary antibody diluted 1:500 in PBS-TX and incubated for $1 \mathrm{hr}$ in the dark (Table 1). In each experiment, control sections were incubated with one primary antibody and then with both secondary antibodies to detect any crossreaction between primary and secondary antibodies. In these conditions, only one staining was evident, indicating no cross-reactivity between the antibodies used. Additional control experiments were performed for the D5 receptor immunohistochemistry by preabsortion of the D5 antiserum with the fusion protein. In this case, $1 \mu \mathrm{l}$ of anti-D5 antiserum was preabsorbed overnight with $100 \mathrm{nmol}$ of the fusion protein before the immunocytochemistry protocol. Staining in this case was abolished completely. Sections were mounted in PBS/glycerol (1:1) and $2 \%$ DABCO (Sigma), coverslipped, and observed by laser confocal microscopy (Leica).

\section{Results}

\section{Electrophysiological identification of striatal LA and FS interneurons in WT and mutant mice}

In striatal slices prepared from WT, D1R $-/-, \mathrm{D} 2 \mathrm{R}-/-$, D2L $-/-$, and D2R $-/-; \mathrm{D} 2 \mathrm{~L}-/-$ mice, striatal LA and FS interneurons (at least 14 cells for each group of interneurons and each group of mice) were identified by morphological and electrophysiological criteria. LA interneurons were easily recognized in striatal slices for their large somata (25-55 $\mu \mathrm{m}$ diameter), whereas no morphological feature allowed us to distinguish the rare FS interneurons $(\sim 1$ of 60 recorded cells) from the more frequently encountered medium spiny projection cells. The identification of FS cells, therefore, was only electrophysiological, 3-5 min after rupture by suction of a tight $G \Omega$ seal made between the recording electrode and a small (10-25 $\mu \mathrm{m}$ diameter) striatal cell. The properties of both LA cholinergic and FS PV-positive neurons were indistinguishable in all the groups of animals tested, resembling those reported previously (Jiang and North, 1991; Kawaguchi, 1992, 1993; Kawaguchi et al., 1995; Plenz and Kitai, 1998; Bennett and Wilson, 1999; Koos and Tepper, 1999; Pisani et al., 2000; Bracci et al., 2002).

LA cells had resting membrane potentials of approximately 

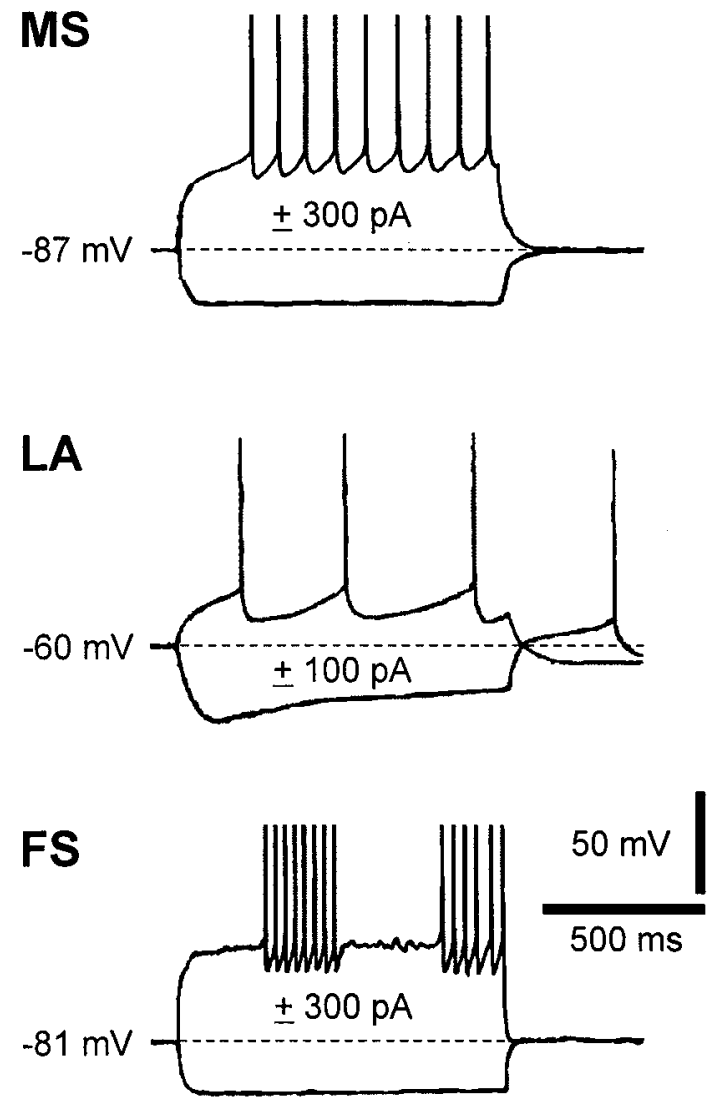

Figure 1. Electrophysiological responses of distinct neuronal subtypes of the striatum to the injection of depolarizing and hyperpolarizing current steps. Note that whereas medium spiny projection neurons (MS) exhibit tonic firing activity with little afterhyperpolarization during positive current pulses, LA and FS interneurons present distinct firing patterns and pronounced afterhyperpolarizations. The dotted line represents the resting membrane potential of the three neurons. See Results for further details.

$-60 \mathrm{mV}$, larger input resistances, lower thresholds for spike generation, and afterhyperpolarizations of longer duration and amplitude than the other classes of striatal cells. In addition, during hyperpolarizing current pulses, they showed a time-dependent decline of the electrotonic potential, which has been demonstrated to follow the activation of a hyperpolarization-activated cation current $\left(I_{\mathrm{h}}\right)$ (Jiang and North, 1991; Kawaguchi, 1993; Bennett and Wilson, 1999). Conversely, all FS interneurons were strongly hyperpolarized (approximately $-78 \mathrm{mV}$ ) and silent at rest. In response to current injections, they fired narrow action potentials followed by large afterhyperpolarizations, displaying a high maximal firing rate (up to $200 \mathrm{~Hz}$ ) with little adaptation. Intermittent burst firing was usually observed in response to moderate positive current steps, whereas no time- and voltagedependent membrane potential declines were observed during hyperpolarizing steps (Fig. 1).

\section{Effects of DA receptor stimulation on the resting membrane potential of LA and FS interneurons of WT and D1R-/- mice}

Recent electrophysiological evidence showed that stimulation of DA D1-like receptors depolarizes both LA (Aosaki et al., 1998; Pisani et al., 2000) and FS interneurons (Bracci et al., 2002) of the rat striatum. In this part of the study, therefore, we investigated whether the excitatory effect of DA on both neuronal subtypes is also present in mice. Second, we assessed how the selective dis- ruption of the D1 member of the D1-like subfamily of DA receptors in these cells would affect the DAergic response.

Bath application of DA (10-100 $\mu \mathrm{M} ; 5-7 \mathrm{~min} ; n=7)$ produced a membrane depolarization in LA interneurons recorded from WT mice. This effect was reversible at the wash-out of the drug and was prevented by the DA D1-like receptor antagonist SCH $23390(10 \mu \mathrm{M})(n=4 ; p<0.01)$ but not by the DA D2-like receptor antagonist L-sulpiride $(3-10 \mu \mathrm{M})(n=5 ; p>0.05)$. The depolarizing effect of DA persisted unchanged in the presence of the sodium channel blocker TTX $(1 \mu \mathrm{M})$, indicating that it was mediated by the activation of D1-like receptors located on the somatodendritic region of the recorded cells $(n=6 ; p<0.001)$.

Essentially similar results were obtained when the effects of DA were measured on the membrane properties of FS interneurons of WT mice. DA $(10-100 \mu \mathrm{M} ; 5-7$ min bath application; $n=$ 8), indeed, dose-dependently depolarized these cells. As with LA interneurons, $10 \mu \mathrm{M}$ SCH 23390 blocked this effect $(n=3)$, whereas neither L-sulpiride $(10 \mu \mathrm{M} ; n=4) \operatorname{nor} \operatorname{TTX}(1 \mu \mathrm{M} ; n=6)$ had any effect.

In D1R - / - mice, DA was still able to depolarize both LA $(n=6)$ and FS interneurons $(n=5)$. In both neuronal subtypes, the DA-dependent membrane depolarizations were comparable between the two genotypes. This suggests that D5 receptors are the main receptors involved in the excitatory effects of DA on these interneurons. Accordingly, also in D1R $-/-$ mice, preincubation of the slices with the DA D1 and D5 receptor blocker SCH $23390(10 \mu \mathrm{M})$ prevented the DA excitation in both neuronal subtypes ( $n=4$ for both LA and FS cells), whereas L-sulpiride (10 $\mu \mathrm{M}$ ) was ineffective ( $n=4$ for LA cells and $n=3$ for FS interneurons) (Fig. 2).

\section{Expression of D5 receptors in cholinergic and PV-containing striatal interneurons}

In a previous study in the rat caudoputamen (Rivera et al., $2002 \mathrm{~b}$ ), it was found that medium spiny neurons and interneurons express D5 receptors. In the present study we have investigated the expression of D5 receptors in cholinergic and PVpositive interneurons in mice lacking DA D1 receptors in an effort to determine whether the absence of D1 receptors has altered the expression patterns of the other member of the D1-like class of receptors, the D5 receptor subtype. We have performed double-labeled immunofluorescence experiments combining our anti-D5 antiserum with an antiserum against ChAT to label cholinergic neurons or with an antibody against PV to label FS cells in striatal sections of WT and D1R $-/-$ mice. The distribution pattern of D5 receptors that we have observed with our anti-D5 receptor antiserum is identical to the distribution pattern shown with other anti-D5 antibodies that were raised in different species and against different epitopes of the antigen (Bergson et al., 1995a,b; Luedtke et al., 1999; Ciliax et al., 2000; Khan et al., 2000). These results confirm the specificity of our antibody. Thus, D5 receptors are expressed in medium and large cells in the striatum of WT and D1R $-/-$ mice (Fig. 3). This immunoreactivity is associated mainly with cell bodies, labeling the cytoplasm and often the primary dendrites too. We have found that all cholinergic neurons in the caudoputamen and nucleus accumbens expressed D5 receptors in both WT and D1R $-/-$ mice (Fig. 3A-F).

Most of the PV-positive neurons also expressed D5 receptors. As in a previous report in the rat (Rivera et al., 2002b), colocalization of D5 receptors with PV in the mouse striatal neurons was more frequent in the rostral than in the caudal part. In addition, 

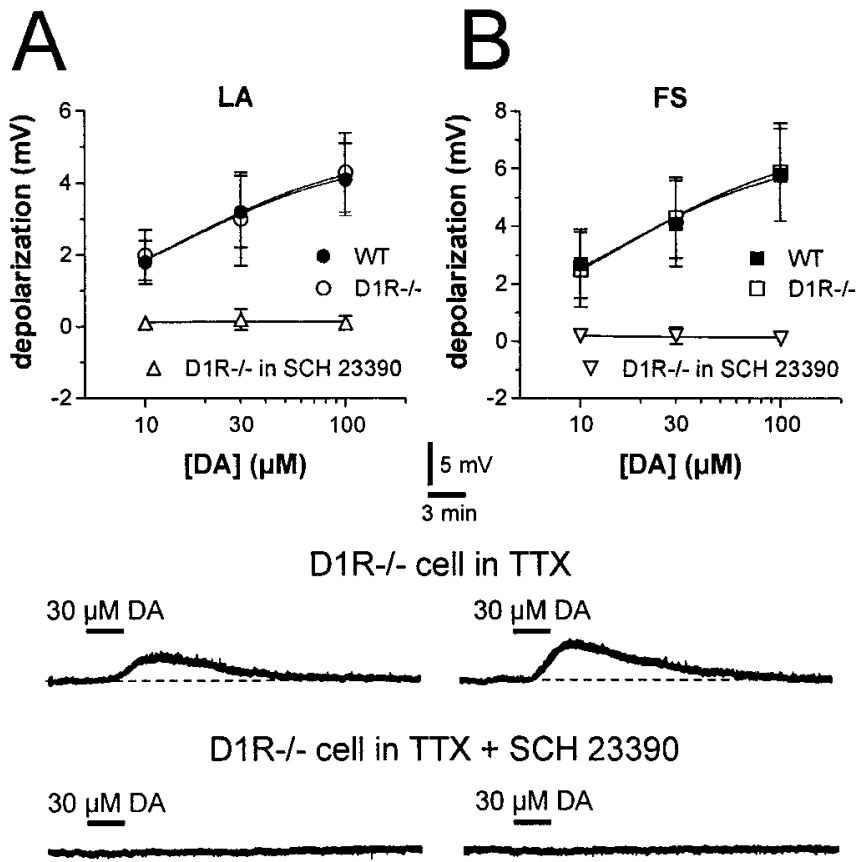

Figure 2. Dopamine depolarizes $L A$ and FS interneurons of both WT and D1R $-/-$ mice. $A$, The graph shows the dose-response relationship for the depolarizing effect of DA on LA interneurons from WT and D1R $-/-$ mice (in the control condition and in the presence of $10 \mu \mathrm{M}$ $\mathrm{SCH}$ 23390). Electrophysiological traces from a single experiment show that bath application of $30 \mu \mathrm{m} \mathrm{DA}$ (black line), in the presence of $1 \mu \mathrm{M} \mathrm{TTX}$, produces a reversible membrane depolarization in a D1R - / - LA interneuron (top trace). In the same cell, the depolarizing effect of DA is fully prevented by the DA D1-like receptor antagonist SCH 23390 (10 $\mu$ m; bottom trace). $B$, The graph shows the dose-response relationship for the depolarizing effect of DA on FS interneurons from WT and D1R $-/-$ mice (in the control condition and in the presence of $10 \mu \mathrm{M}$ $\mathrm{SCH}$ 23390). Electrophysiological traces from a single experiment show that bath application of $30 \mu \mathrm{M}$ DA (black line), in the presence of $1 \mu \mathrm{M} \mathrm{TTX}$, produces a membrane depolarization in a $D 1 R-/-F S$ interneuron (top trace). In the same neuron, the depolarizing effect of DA is fully prevented by the DA D1-like receptor antagonist SCH 23390 (10 $\mu \mathrm{m}$; bottom trace). Resting membrane potentials are $-58 \mathrm{mV}$ in $A$ and $-78 \mathrm{mV}$ in $B$.

double-labeled cells were distributed preferentially in the lateral striatum. These observations were made in the WT and D1R-/mice and indicate that the absence of D1 receptor does not modify the expression pattern of D5 receptors. Moreover, the similarity of the staining in WT and D1R-/- mice indicates that our anti-D5 antiserum does not recognize D1 receptors, despite their homology (Fig. 3G-L).

\section{Immunoblot characterization of the D5 receptor antiserum}

Affinity-purified anti-D5 receptor antiserum was characterized to study its specificity by Western blot analysis in tissue extracts from cortex, striatum, and hippocampus of mouse and rat brains. Figure $4 A$ shows representative results obtained with murine tissue extracts. The bands observed consisted of a doublet and a single band migrating with a molecular mass of $\sim 64-70 \mathrm{kDa}$ $(n=7)$ and a lower molecular band migrating approximately at $40 \mathrm{kDa}$. These bands were consistently observed in hippocampus, striatum, and cortex (Fig. 4A, lanes 1, 2, and 3, respectively), in both rat and mouse. Because the theoretical molecular weight of D5 receptors is $53 \mathrm{kDa}$ [calculated from the amino acid sequence (Sunahara et al., 1991; Tiberi et al., 1991)], our 64-70 kDa bands may correspond to different glycosylation forms of the protein or other posttranslational modifications (Bergson et al., 1995a,b; Ciliax et al., 2000), whereas the low molecular mass bands $(\sim 40$
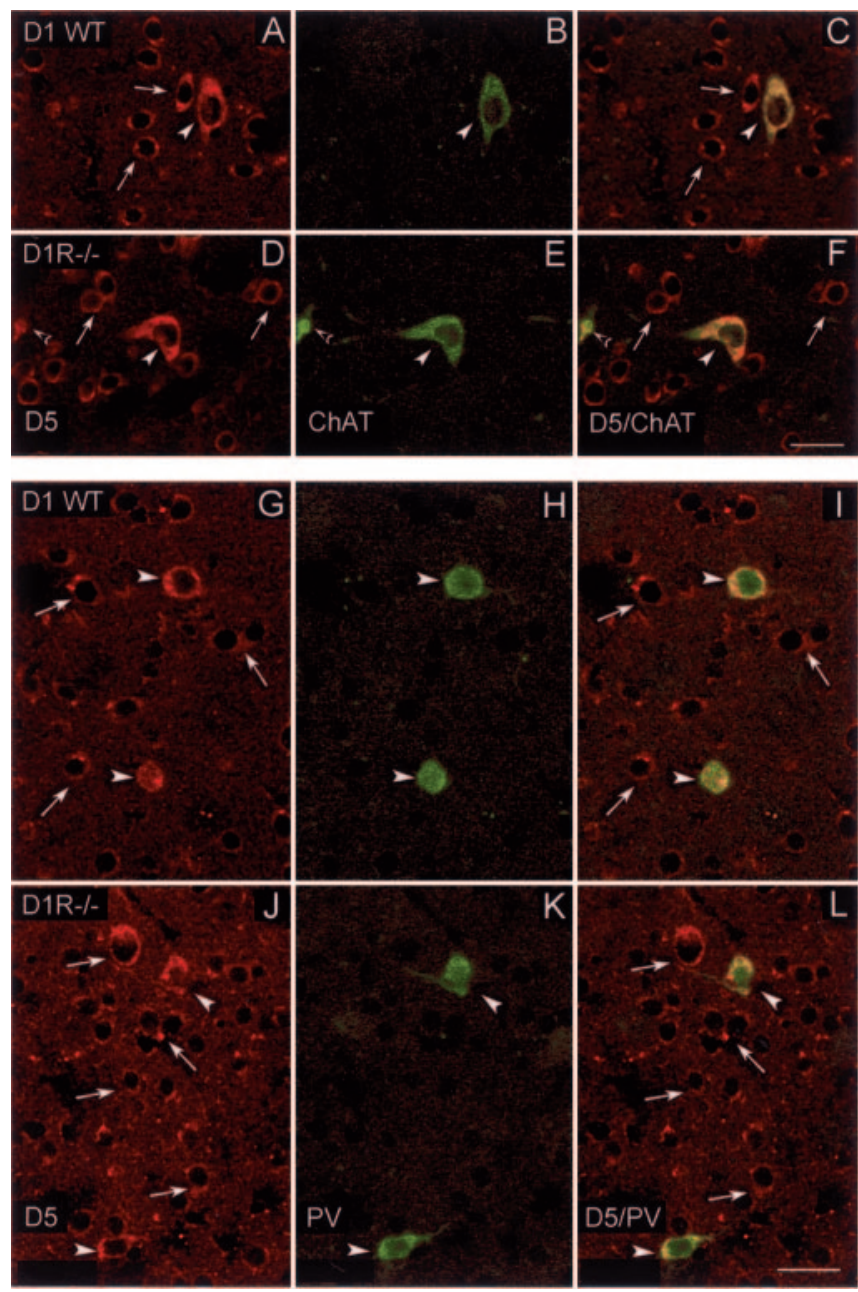

Figure 3. Confocal laser photomicrographs illustrating the colocalization of D5 receptors with choline acetyltransferase (ChAT) and parvalbumin (PV) in striatal interneurons of WT and DA D1R - / - mice. $A, D$, Striatal neurons expressing DA D5 receptors in WT $(A)$ and in D1R $-/-$ mice $(D) ; B, E$, striatal interneurons containing ChAT in WT $(B)$ and in D1R $-/-$ mice (E). $C$ and $F$ show paired images illustrating double-labeled cells with D5/ChAT in WT $(C)$ and D1R $-/-$ mice $(F$. Note in Cand $F$ that ChAT-positive neurons express D5 receptors in WT and $D 1 R-/-$ mice. Open arrowheads in $D-F$ indicate a cholinergic partial cell that also expresses D5 receptors. $G, J$, Striatal neurons expressing DA D5 receptors in WT $(G)$ and in D1R $-/-$ mice $(J) ; H, K, P V$-containing interneurons located in the striatum of WT $(H)$ and D1R $-/-$ mice $(K)$. Paired images in I and $L$ show double-labeled cells with D5/PV in WT (I) and D1R - $/$ - mice (L). White arrows indicate single-labeled cells for D5 receptors, and arrowheads indicate double-labeled cells in the corresponding images. Note in $/$ and $L$ that PV-containing neurons also express D5 receptors in WT and in D1R $-/-$ mice. Scale bars, $25 \mu \mathrm{m}$.

$\mathrm{kDa}$ ) may represent degradation products of D5 receptors ( $\mathrm{Lu}-$ edtke et al., 1999; Ciliax et al., 2000).

Occasionally another immunoreactive band of a higher molecular weight $(\sim 120 \mathrm{kDa})$ was also observed (Fig. $4 B)$. This band may correspond to a covalently dimerized D5 receptor, as has also been shown by other laboratories using a polyclonal antiserum (Bergson et al. 1995a,b; Ciliax et al., 2000) or a monoclonal antibody (Luedtke et al., 1999). These antibodies have also been raised against a fusion protein similar to the fusion protein that we have used. Preabsorption of the antibody with the fusion protein overnight prevented the appearance of the bands (Fig. 4, lanes 4, 5, and 6 for hippocampus, striatum, and cortex, respectively). However, preabsorption of our antiserum with an unrelated GST-fusion protein did not prevent staining of the bands (data not shown). Liver extracts processed at the same time with 

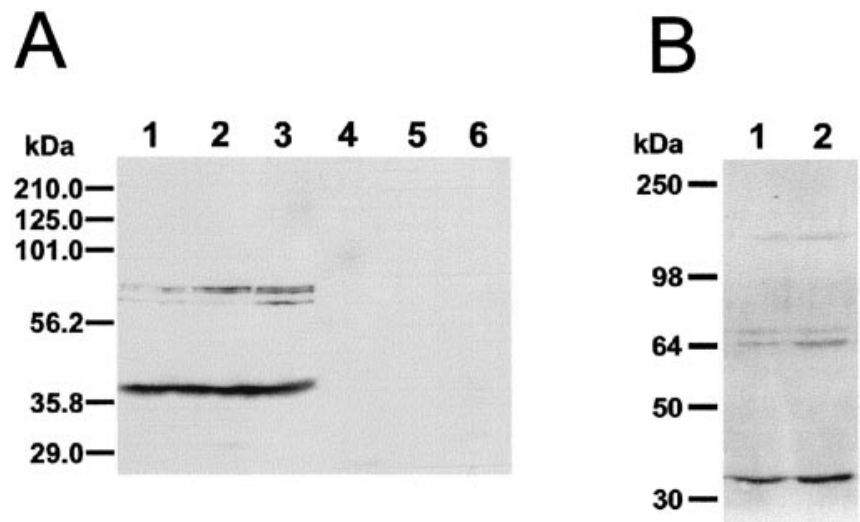

Figure 4. Western blot analysis of anti-D5 antiserum immunoreactivity in mouse brain tissue extracts. $A$, Immunoreactive bands obtained in tissue extracts of the mouse brain stained with an anti-D5 receptor antiserum (lanes 1-3) or with the antiserum previously preabsorbed with the D5-fusion protein (lanes $4-6$ ). Note three bands with a molecular weight $\sim 65 \mathrm{kDa}$ and another band migrating with a lower molecular mass $(\sim 40 \mathrm{kDa})$. Shown is the extract from hippocampus (lanes 1, 4), striatum (lanes 2, 5), and prefrontal cortex (lanes 3, 6). B, Immunoreactive bands obtained from tissue extracts of striatum (lane 1 ) and cortex (lane 2). Two bands migrating at $\sim 65 \mathrm{kDa}$, another band with lower molecular mass $(\sim 40 \mathrm{kDa})$, and another band of higher molecular mass $(\sim 120 \mathrm{kDa})$ were observed. This latter band may correspond to dimerization of D5 receptors. The position of prestained molecular weight standards is shown to the left of the immunoblot autoradiograms.

brain tissue did not show any immunoreactivity (data not shown). These results confirm the specificity of our antiserum.

\section{Effects of DA D2-like receptor stimulation on $\mathrm{GABA}_{\mathrm{A}^{-}}$ mediated synaptic inputs to WT and D2R $-/-$ striatal interneurons}

Stimulation of DA D2-like receptors depresses $\mathrm{GABA}_{\mathrm{A}}$-mediated inhibitory synaptic inputs to both LA (Pisani et al., 2000; Momiyama and Koga, 2001) and FS striatal interneurons (Bracci et al., 2002). Voltage-clamp recordings therefore were performed from single LA or FS interneurons to evoke IPSCs in WT and $\mathrm{D} 2 \mathrm{R}-/-$ mice. In both groups of animals and interneurons, IPSCs were recorded after intrastriatal stimulation in the presence of MK-801 $(30 \mu \mathrm{M})$ and CNQX $(10 \mu \mathrm{M})$ to block NMDA and AMPA glutamate receptors, respectively. In this experimental condition, the evoked synaptic currents were completely sensitive to bicuculline ( $3 \mu \mathrm{M} ; n=4$ for each genotype and neuronal subtype), confirming their $\mathrm{GABA}_{\mathrm{A}}$-mediated nature, and were detected as outward deflections when the membrane potential of WT or $\mathrm{D} 2 \mathrm{R}-/-$ interneurons were depolarized to $0 \mathrm{mV}$. All $\mathrm{GABA}_{\mathrm{A}}$-mediated IPSCs were evoked at this holding potential.

To identify the receptor subtype mediating the effects of DA D2-like receptor stimulation on striatal interneuron inhibitory inputs, we tested the effects of the genetic ablation of D2 receptors on the quinpirole-mediated inhibition of striatal IPSCs recorded from both LA and FS cells. The DA D2-like receptor agonist quinpirole (1-30 $\mu \mathrm{M} ; 5-7 \mathrm{~min})$ failed to affect GABAergic IPSCs in both LA $(n=6 ; p>0.05)$ and FS interneurons of D2R-/mice $(n=5 ; p>0.05)$, whereas it produced a significant and reversible inhibition of IPSC amplitude in both neuronal subtypes of WT mice ( $n=5$ and $p<0.001$ for LA and FS cells) (Fig. $5)$. Furthermore, in WT interneurons, the depressant action of 10 $\mu \mathrm{M}$ quinpirole on IPSC amplitude was effectively antagonized by subsequent application of $10 \mu \mathrm{M}$ L-sulpiride $(n=2$ for LA cells and $n=3$ for FS cells), confirming that it was mediated by the stimulation of D2Rs (data not shown).
A
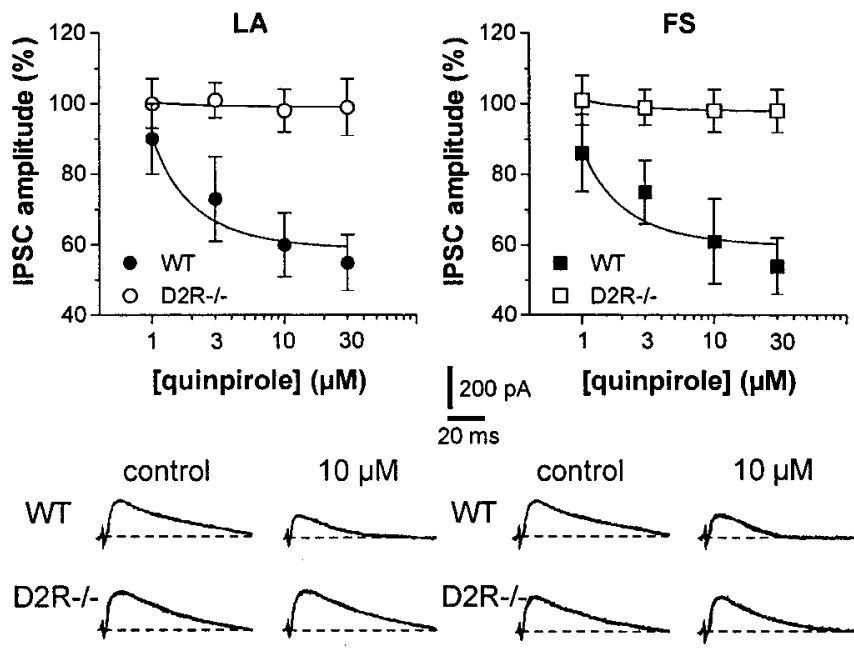

Figure 5. Stimulation of DA D2-like receptor inhibits GABAergic synaptic transmission in WT but not in $\mathrm{D} 2 \mathrm{R}-1-$ mice. $A$, The graph shows the dose-dependent inhibition of GABAergic synaptic transmission by quinpirole in LA interneurons of WT but not $D 2 R-1-$ mice. The traces from single experiments show the effect of $10 \mu \mathrm{m}$ quinpirole on IPSCs recorded from $L A$ neurons of WT and D2R - / - animals. B, The graph shows the dose-dependent inhibition of GABAergic synaptic transmission by quinpirole in FS interneurons from WT and D2R $-/-$ mice. Similar to LA cells, FS interneurons from the D2R - / - group are not sensitive to quinpirole. The traces from single experiments show the effect of $10 \mu \mathrm{m}$ quinpirole on IPSCs recorded from FS neurons of WT and D2R-/ - animals.

Effects of quinpirole on $\mathrm{GABA}_{\mathrm{A}}$-mediated IPSCs recorded from $\mathrm{LA}$ and $\mathrm{FS}$ interneurons of $\mathrm{D} 2 \mathrm{~L}-/-$ and D2R-/-;D2L-/- mice

Two isoforms of the D2 receptor are generated from the same gene by alternative splicing: D2L and D2S isoform. Interestingly, D2L and D2S receptors display differential affinities for inhibitory G-proteins (Guiramand et al., 1995) and have been suggested to serve distinct physiological roles (Usiello et al., 2000; Wang et al., 2000). To identify which D2 receptor isoform is involved in the inhibition of $\mathrm{GABA}_{\mathrm{A}}$ transmission in LA and FS cells, D2L-/- mice were used.

In both LA $(n=5)$ and FS interneurons $(n=5)$ of $\mathrm{D} 2 \mathrm{~L}-/-$ mice, quinpirole (1-30 $\mu \mathrm{M})$ caused a dose-dependent depression of IPSC amplitude, which was prevented by preincubation of the slices with L-sulpiride ( $10 \mu \mathrm{M} ; n=3$ for both neuronal subtypes) and was essentially identical to that observed in the WT counterparts ( $n=4$ for both LA and FS interneurons) (Fig. 6).

Increased expression of D2S receptors has been described in D2L-/- mice (Usiello et al., 2000). The normal sensitivity to quinpirole observed in $\mathrm{D} 2 \mathrm{~L}-/-$ mice, therefore, might be ascribed to this compensatory effect, which might fully overcome the requirement of D2L receptors in the quinpirole effects. To answer this question, D2L-/- mice were mated with D2 receptor null mice in an attempt to bring the amount of D2S sites to levels similar to those of WT animals. The pharmacological features of $\mathrm{D} 2 \mathrm{~S}$ receptor binding sites in $\mathrm{D} 2 \mathrm{R}-/-; \mathrm{D} 2 \mathrm{~L}-/-$ mice in comparison with $\mathrm{D} 2 \mathrm{~L}-/-$ mice were assessed by binding assays using $\left[{ }^{3} \mathrm{H}\right]$ spiperone, as described previously (Baik et al., 1995; Usiello et al., 2000). The results of these experiments showed that in $\mathrm{D} 2 \mathrm{R}-/-; \mathrm{D} 2 \mathrm{~L}-/-$ mice the maximum binding capacities were strongly reduced as compared with D2L-/- and WT mice (Table 2).

In LA $(n=4)$ and FS interneurons $(n=4)$ of D2R-/-; 

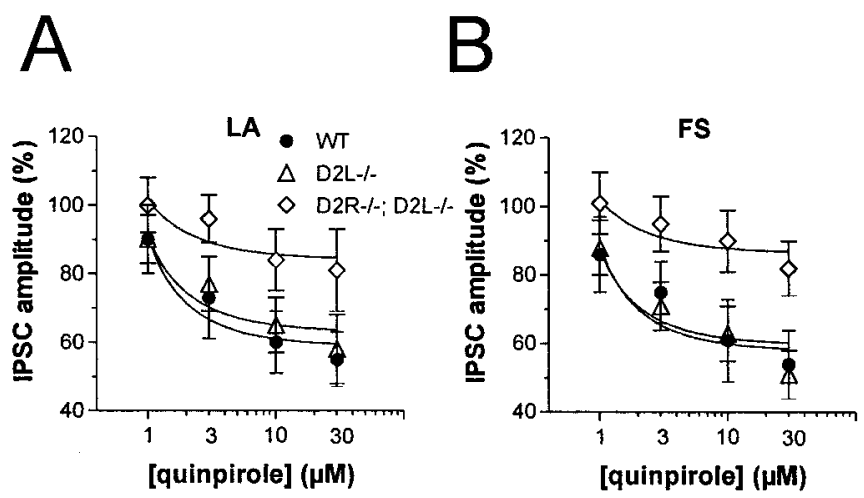

Figure 6. Effects of $\mathrm{D} 2$ receptor stimulation in $\mathrm{D} 2 \mathrm{~L}-1-$ and $\mathrm{D} 2 \mathrm{R}-1-; \mathrm{D} 2 \mathrm{~L}-1-$ mice. $A$, The graph shows the inhibitory effect of different doses of quinpirole (1-30 $\mu \mathrm{M})$ on the amplitude of GABAergic IPSCs recorded from LA interneurons of WT, D2L $-1-$, and D2R $-1-$; D2L $-/-$ mice. Although WT and D2L knock-outs respond to quinpirole in a similar manner, $\mathrm{D} 2 \mathrm{R}-1-; \mathrm{D} 2 \mathrm{~L}-1-$ mice show a significant reduction of sensitivity to quinpirole $(p<0.05$ at 10 and $30 \mu \mathrm{m}$ compared with control amplitudes, and $p<0.01$ at 3,10 , and $30 \mu \mathrm{m}$ quinpirole compared with WT and D2L $-/-$ neurons). $B$, The graph shows the inhibitory effect of different doses of quinpirole (1-30 $\mu \mathrm{M})$ on the amplitude of GABAergic IPSCS recorded from FS interneurons of WT, D2L $-1-$, and D2R $-1-; D 2 L-1-$ mice. FS interneurons from WT and D2L knock-outs respond to quinpirole in a manner similar to that LA cells, whereas those from D2R $-/-; \mathrm{D} 2 \mathrm{~L}-1-$ animals show a significant reduction of sensitivity to quinpirole ( $p<$ 0.05 at 10 and $30 \mu \mathrm{m}$ compared with control amplitudes, and $p<0.01$ at 3,10 , and $30 \mu \mathrm{m}$ quinpirole compared with WT and D2L $-/$ - neurons recorded in the presence of this agonist).

Table 2. $\left[{ }^{3} \mathrm{H}\right]$-spiperone binding in WT, D2L $-/-$, and D2R-/-;D2L $-/-$ mice

\begin{tabular}{lll}
\hline & $K_{\mathrm{d}}(\mathrm{pM})$ & $B_{\max }$ (fmol/mg protein) \\
\hline WT & $114 \pm 12$ & $416 \pm 51$ \\
D2L-I- & $144 \pm 15$ & $497 \pm 56$ \\
D2R-I-;D2L-I- & $77 \pm 13$ & $237 \pm 49$
\end{tabular}

The values represent the mean \pm SEM of three independent experiments, each performed in triplicate.

D2L $-/-$ mice, quinpirole was still able to depress GABA IPSCs $(p<0.05$ for both LA and FS cells at 10 and $30 \mu \mathrm{M})$, although to lower levels $(p<0.01$ at 3,10 , and $30 \mu \mathrm{M}$ quinpirole compared with WT and D2L $-/-$ neurons recorded in the presence in quinpirole) (Fig. 6).

Effects of quinpirole on spontaneous $\mathrm{GABA}_{\mathrm{A}}$-mediated IPSCs in LA interneurons of WT, D2R $-/-, \mathrm{D} 2 \mathrm{~L}-/-$, and $\mathrm{D} 2 \mathrm{R}-/-$; D2L-/- mice

To analyze further the action of quinpirole on $\mathrm{GABA}_{\mathrm{A}}$ transmission, its effect on the frequency and amplitude of spontaneous GABA-mediated IPSCs was examined. Spontaneous GABAergic IPSCs were recorded from LA interneurons by using cesium chloride-based patch pipettes. These pipettes significantly altered the action potential properties of the recorded neurons, thereby preventing the unequivocal identification of FS cells. At the holding potential of $-60 \mathrm{mV}$ and in the presence of $10 \mu \mathrm{M} \mathrm{CNQX}$ and $30 \mu \mathrm{M}$ MK-801, bicuculline-sensitive $(n=5)$ IPSCs were detected as inward currents. As expected for a presynaptic effect, quinpirole (10 $\mu \mathrm{M} ; 7-10 \mathrm{~min}$ application) caused in LA interneurons recorded from WT mice $(n=4)$ a significant $(p<0.01)$ reduction of the frequencies of IPSCs, without altering the amplitudes. This effect was abolished in $\mathrm{D} 2 \mathrm{R}-/-$ mice $(n=5 ; p>$ $0.05)$, remained intact in D2L $-/-$ mice $(n=4 ; p<0.01)$, and was diminished in $\mathrm{D} 2 \mathrm{R}-/-; \mathrm{D} 2 \mathrm{~L}-/-$ LA cells $[n=6 ; p<0.05$ compared with pre-quinpirole levels and with spontaneous IPSCs (sIPSCs) recorded in WT and D2L $-/-$ cells in the presence of quinpirole] (Figs. 7, 8).
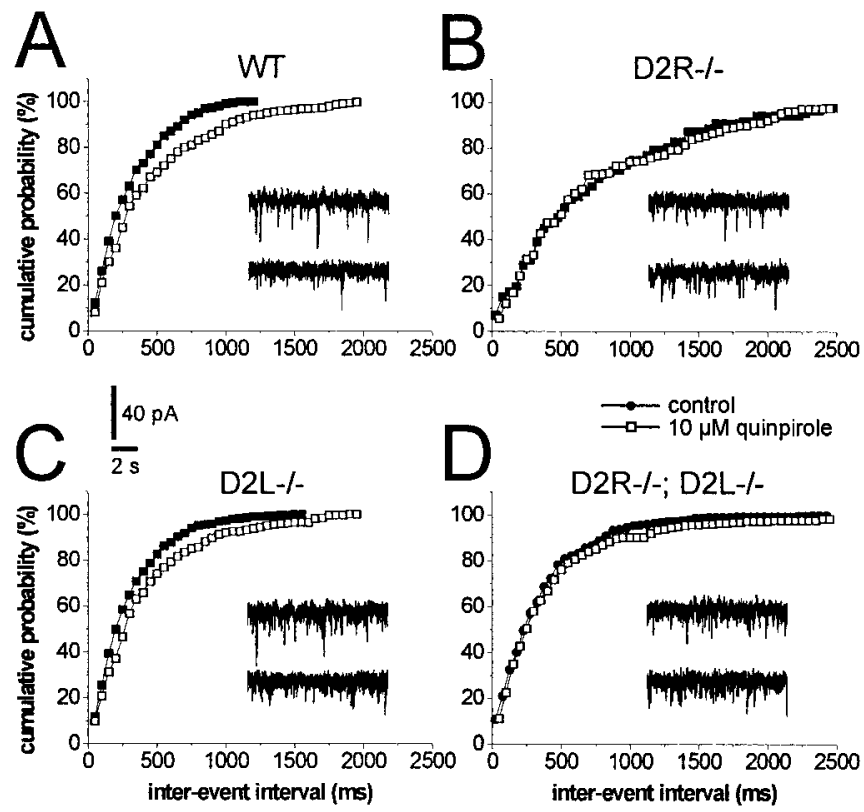

Figure 7. Effects of quinpirole on GABAergic sIPSCS recorded from LA interneurons of WT, $D 2 R-1-, D 2 L-1-$, and $D 2 R-1-; D 2 L-1-$ mice. The graphs are single-cell plots from patch-clamp experiments. In a WT LA interneuron $(A), 10 \mu \mathrm{m}$ quinpirole reduces the frequency of sIPSCS (expressed as inter-event interval). The effect of quinpirole is absent in the D2R $-1-$ LA neuron $(B)$, although it is similar to WTs in the D2L - I- cell ( $C$. In D2R - /-;D2L - I- LA interneurons $(D)$, the effect of quinpirole is reduced.

\section{Discussion}

The results of the present study demonstrated that DA controls striatal interneuron excitability through postsynaptic D5 receptors and presynaptic D2 receptors located on GABAergic nerve terminals. In addition, these studies strongly point to an involvement of both isoforms of the D2 receptor in the presynaptic effects of DA on GABA transmission. Indeed, the inhibitory effect of $\mathrm{D} 2$ receptor stimulation on both evoked and spontaneous $\mathrm{GABA}_{\mathrm{A}}$ currents, lost in $\mathrm{D} 2 \mathrm{R}-/-$ animals, is preserved in $\mathrm{D} 2 \mathrm{~L}-/-$ mice, which express an equal number of D2 binding sites as WT animals, although composed exclusively of the D2S isoform. However, the response of D2L-/- mice was less pronounced when the number of D2S sites was reduced by $50 \%$, leading to a condition of D2S expression closer to that found in WT animals.

D1 receptors are not necessary for the excitatory effects of DA on striatal interneurons

In $\mathrm{D} 1 \mathrm{R}-/-$ as well as WT mice, DA was equally effective in depolarizing LA and FS cells of the striatum. The dose-response relationship of the DA effects in both genotypes was similar also at low concentrations, suggesting no participation of D1 receptors in this electrophysiological effect. Overexpression and overfunctioning of D5 receptors in D1R $-/-$ mice, however, might potentially explain the virtually coincident dose-response curve for the DA effects observed in WT and D1R-/- interneurons. Clearly, the use of the recently generated D5 receptor-lacking mice (Holmes et al., 2001; Hollon et al., 2002) will be essential to strengthening our conclusion. In addition, adaptive changes of non-D1-like receptors might also take place in D1R-/- mice, and this might compensate, in principle, for the impaired D1 receptor-dependent function (Borowsky et al., 2001; Federici et al., 2002). However, the experimental evidence that SCH 23390 was able to fully prevent in D1R-/- mice the excitatory effect of 


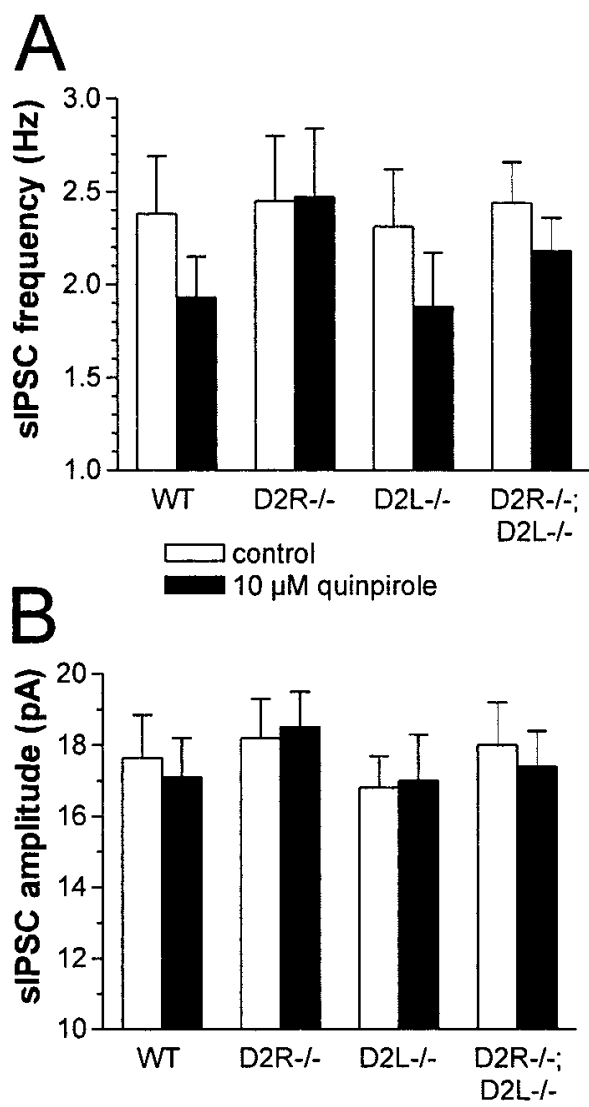

Figure 8. Effect of D2 receptor stimulation on sIPSC frequency and amplitude of WT and mutant LA interneurons. $A$, The histogram shows the average effect of $10 \mu \mathrm{m}$ quinpirole on the frequency of GABAergic sIPSCs recorded from LA interneurons. Cells from WT, D2L $-/-$, and $\mathrm{D} 2 \mathrm{R}-1-; \mathrm{D} 2 \mathrm{~L}-1-$ mice are significantly affected by this drug $(p<0.01$ for both WT and $\mathrm{D} 2 \mathrm{~L}-1-$ mice and $p<0.05$ for $\mathrm{D} 2 \mathrm{R}-/-; \mathrm{D} 2 \mathrm{~L}-/-$ mice). The quinpirole-mediated synaptic inhibition observed in $\mathrm{D} 2 \mathrm{R}-/-; \mathrm{D} 2 \mathrm{~L}-/-$ neurons, however, was significantly less pronounced than the one observed in WT and D2L $-1-$ mice ( $p<0.05$ compared with both WT and $\mathrm{D} 2 \mathrm{~L}-/-$ neurons). $B$, In the three genotypes, the reduction of sIPSC frequency is not paralleled by changes in their amplitude $(p>0.05)$, suggesting a presynaptic mechanism for this phenomenon.

DA in both LA and FS cells rules out this hypothesis because unconventional DA receptors have been reported to be insensitive to the classical antagonists of DA D1-like and D2-like receptors, including SCH 23390 (Federici et al., 2002).

The D1 receptor subtype in the striatum is much more abundant than the D5 receptor subtype. We now know that the pattern of expression of these two receptor subtypes in the striatum is complementary to a large extent. Although D1 receptors are strongly expressed in projection neurons (Surmeier et al., 1996), D5 receptors are preferentially expressed in striatal interneurons and weakly expressed in projection neurons (Bergson et al., 1995b; Rivera et al., 2002b). The presence of D5 receptors in cholinergic cells has been demonstrated by single-cell RT-PCR (Yan and Surmeier, 1997) and by double-label immunofluorescence experiments (Rivera et al., 2002b) in which it was demonstrated that all cholinergic cells expressed D5 receptors. In addition, Yan and Surmeier (1997) demonstrated that most of these cells do not express D1 receptors. On the basis of these findings, previous works conducted on striatal LA interneurons already argued that D5 receptors mediate the electrophysiological actions of D1-like receptor agonists on these cells (Yan and Surmeier, 1997; Aosaki et al., 1998). Our double-label immunofluorescence data combined with our electrophysiological study on mice lack- ing D1 receptors provides solid evidence that D5 receptor mediates the electrophysiological effects of D1/D5 ligands because no available pharmacological agent discriminates between D1 and D5 receptors, and D1 receptor mRNA has been detected, although rarely, in isolated LA cells (Yan et al., 1997).

In the same direction, the presence of D1 receptors in FS $\mathrm{PV}$-positive neurons in the striatum is still inconclusive. However, our double-label immunofluorescence data indicating the presence of D5 receptors in PV cells in D1R $-/-$ mice provides strong evidence that the D5 receptor is the DA receptor subtype involved in the depolarizing action of DA in these striatal interneurons.

\section{D2 receptors mediate the inhibitory action of DA on GABAergic inputs to striatal interneurons}

GABA-mediated inputs to both LA and FS interneurons have an essentially identical sensitivity to DA D2 receptor stimulation. Genetic manipulation of D2 receptor expression leads to comparable changes of the sensitivity of both neuronal types. These results strongly suggest that LA and FS interneurons receive the same type of GABAergic afferents. Interestingly, GABAergic innervation of the striatum is almost totally intrinsic, originating from recurrent collaterals of projection neurons or from GABAergic interneurons (Wilson and Groves, 1980; Bennett and Bolam, 1994; Yung et al., 1996; Plenz and Kitai, 1998; Koos and Tepper, 1999). Although recurrent collaterals of spiny neurons form a dense intrastriatal network (Wilson and Groves, 1980; Wickens et al., 1995; Beiser and Houk, 1998), functional studies showed that activation of one spiny neuron rarely triggers synaptic events in another nearby neuron (Jaeger et al., 1994; Tunstall et al., 2002). By contrast, action potentials evoked in an FS interneuron have been found capable of producing stronger GABAmediated synaptic events in spiny neurons (Plenz and Kitai, 1998; Koos and Tepper, 1999), suggesting that GABAergic interneurons, rather than axon collaterals of spiny cells, exert the predominant inhibitory control of striatal neuron excitability.

The origin of the GABAergic input to striatal interneurons, however, remains to be clarified. Dual recordings suggested that it does not come from projection neurons (Koos and Tepper, 1999, 2002), although pallidal afferents may be involved (Bevan et al., 1998). Notably, GABAergic interneurons are the principal candidates for the synaptic inhibition of striatal LA and FS interneurons. GABAergic interneurons, in fact, have a dense arborization of axon collaterals within the striatum, extensively contact perikarya and dendrites of several striatal cells, including interneurons themselves (Chang and Kita, 1992; Kita, 1993; Kawaguchi et al., 1995), and express D2 receptors on their nerve terminals (Delle Donne et al., 1997).

\section{Concluding remarks}

DA is a crucial regulator of striatal function. Loss of nigrostriatal DAergic projection, in fact, causes severe motor abnormalities in Parkinson's disease patients and in animal models of parkinsonism (Bergman et al., 1998; Obeso et al., 2000). In addition, a disordered striatal DAergic transmission is involved in other neuropsychiatric disorders such as schizophrenia and drug addiction (Berke and Hyman, 2000; Lewis and Lieberman, 2000; Hyman and Malenka, 2001). Despite the importance of this transmitter in critical brain activities, however, the cellular mechanisms by which DA affects striatal neuron excitability are mostly unknown. The effects of DA on projection spiny neurons have been investigated extensively in recent years. The results obtained led to the discovery that DA, particularly via D1 receptor activation, 
exerts a complex modulation of striatal output, depending mainly on the membrane potential of the neuron during the activation of DA signal (Nicola et al., 2000; Centonze et al., 2001). Conversely, only a few studies have been devoted to the investigation of the action of this transmitter on striatal interneurons. By modulating the activity of interneurons, DA exerts a potent, although indirect, control on the final output of the striatum, because the projection neurons of this brain area are finely regulated by interneurons (Calabresi et al., 2000; Koos and Tepper, 1999, 2002). Our study supports the conclusion that DA has a complex modulatory effect on the physiological activity of both cholinergic and GABAergic interneurons of the striatum by targeting presynaptic and postsynaptic cellular sites and distinct receptor subtypes.

In this study we identified components of the DA receptor family involved in DA regulation of striatal interneurons. This is an important step in understanding the physiology of the basal ganglia and in developing pharmacological compounds that are able to target selectively a specific neuronal function.

\section{References}

Aosaki T, Kiuchi K, Kawaguchi Y (1998) Dopamine D1-like receptor activation excites rat striatal large aspiny neurons in vitro. J Neurosci 18:5180-5190.

Arbuthnott GW, Ingham CA, Wickens JR (2000) Dopamine and synaptic plasticity in the neostriatum. J Anat 196:587-596.

Baik JH, Picetti R, Saiardi A, Thiriet G, Dierich A, Depaulis A, Le Meur M, Borrelli E (1995) Parkinsonian-like locomotor impairment in mice like dopamine D2 receptors. Nature 377:424-428.

Beiser DG, Houk JC (1998) Model of cortical-basal ganglionic processing: encoding the serial order of sensory events. J Neurophysiol 79:3168-3188.

Bennett BD, Bolam JP (1994) Synaptic input and output of parvalbuminimmunoreactive neurons in the neostriatum of the rat. Neuroscience 62:707-719.

Bennett BD, Wilson CJ (1999) Spontaneous activity of neostriatal cholinergic interneurons in vitro. J Neurosci 19:5586-5596.

Bergman H, Feingold A, Nini A, Raz A, Slovin H, Abeles M, Vaadia E (1998) Physiological aspects of information processing in the basal ganglia of normal and parkinsonian primates. Trends Neurosci 21:32-38.

Bergson C, Mrzljak L, Lidow MS, Goldman-Rakic PS, Levenson R (1995a) Characterization of subtype-specific antibodies to the human D5 dopamine receptor: studies in primate brain and transfected mammalian cells. Proc Natl Acad Sci USA 92:3468-3472.

Bergson C, Mrzljak L, Smiley JF, Pappy M, Levenson R, Goldman-Rakic PS (1995b) Regional, cellular, and subcellular variations in the distribution of D1 and D5 dopamine receptors in primate brain. J Neurosci 15:7821-7836.

Berke JD, Hyman SE (2000) Addiction, dopamine, and the molecular mechanisms of memory. Neuron 25:515-532.

Bevan MD, Booth PAC, Eaton SA, Bolam JP (1998) Selective innervation of neostriatal interneurons by a subclass of neuron in the globus pallidus of the rat. J Neurosci 18:9438-9452.

Borowsky B, Adham N, Jones KA, Raddatz R, Artymyshyn R, Ogozalek KL, Durkin MM, Lakhlani PP, Bonini JA, Pathirana S, Boyle N, Pu X, Kouranova E, Lichtblau H, Ochoa Y, Branchek TA, Gerald C (2001) Trace amines: identification of a family of mammalian $G$ protein-coupled receptors. Proc Natl Acad Sci USA 98:8966-8971.

Bracci E, Centonze D, Bernardi G, Calabresi P (2002) Dopamine excites fast spiking interneurons in the striatum. J Neurophysiol 87:2190-2194.

Calabresi P, Mercuri NB, Stanzione P, Stefani A, Bernardi G (1987) Intracellular studies on the dopamine-induced firing inhibition of neostriatal neurons in vitro: evidence for D1 receptor involvement. Neuroscience 20:757-771.

Calabresi P, Saiardi A, Pisani A, Baik J-H, Centonze D, Mercuri NB, Bernardi G, Borrelli E (1997) Abnormal synaptic plasticity in the striatum of mice lacking dopamine D2 receptors. J Neurosci 17:4536-4544.

Calabresi P, Centonze D, Gubellini P, Pisani A, Bernardi G (2000a) Acetylcholine-mediated modulation of striatal function. Trends Neurosci 23:120-126.
Calabresi P, Gubellini P, Centonze D, Picconi B, Bernardi G, Chergui K, Svenningsson P, Fienberg AA, Greengard P (2000b) Dopamine and cyclic adenosine $3^{\prime}, 5^{\prime}$ monophosphate-regulated phosphoprotein $32 \mathrm{kDa}$ controls both striatal long-term depression and long-term potentiation, opposing forms of synaptic plasticity. J Neurosci 20:8443-8451.

Centonze D, Picconi B, Gubellini P, Bernardi G, Calabresi P (2001) Dopaminergic control of synaptic plasticity in the dorsal striatum. Eur J Neurosci 13:1071-1077.

Centonze D, Picconi B, Baunez C, Borrelli E, Pisani A, Bernardi G, Calabresi P (2002) Cocaine and amphetamine depress striatal GABAergic synaptic transmission through D2 dopamine receptors. Neuropsychopharmacology 26:164-175.

Cepeda C, Buchwald NA, Levine MS (1993) Neuromodulatory actions of dopamine in the neostriatum are dependent on the excitatory amino acid receptor subtypes activated. Proc Natl Acad Sci USA 90:9576-9580.

Cepeda C, Colwell CS, Itri JN, Chandler SH, Levine MS (1998) Dopaminergic modulation of NMDA-induced whole cell currents in neostriatal neurons in slices: contribution of calcium conductances. J Neurophysiol 79:82-94.

Cepeda C, Hurst RS, Altemus KL, Flores-Hernàndez J, Calvert CR, Jokel ES, Grandy DK, Low MJ, Rubinstein M, Ariano MA, Levine MS (2001) Facilitated glutamatergic transmission in the striatum of $\mathrm{D}_{2}$ dopamine receptor-deficient mice. J Neurophysiol 85:659-670.

Chang HT, Kita H (1992) Interneurons in the rat striatum: relationships between parvalbumin neurons and cholinergic neurons. Brain Res 574:307-311.

Ciliax BJ, Nash N, Heilman C, Sunahara R, Hartney A, Tiberi M, Rye DB, Caron MG, Niznik HB, Levey AI (2000) Dopamine D(5) receptor immunolocalization in rat and monkey brain. Synapse 37:125-145.

Delgado A, Sierra A, Querejeta E, Valdiosera RF, Aceves J (2000) Inhibitory control of the GABAergic transmission in the rat neostriatum by D2 dopamine receptors. Neuroscience 95:1043-1048.

Delle Donne KT, Sesack SR, Pickel VM (1997) Ultrastructural immunocytochemical localization of the dopamine D2 receptor within GABAergic neurons in the rat striatum. Brain Res 746:239-255.

Federici M, Natoli S, Bernardi G, Mercuri NB (2002) Dopamine selectively reduces $\mathrm{GABA}_{\mathrm{B}}$ transmission onto dopaminergic neurones by an unconventional presynaptic action. J Physiol (Lond) 540:119-128.

Flores-Hernandez J, Hernandez S, Snyder GL, Yan Z, Fienberg AA, Moss SJ, Greengard P, Surmeier DJ (2000) $D_{1}$ dopamine receptor activation reduces $\mathrm{GABA}_{\mathrm{A}}$ receptor currents in neostriatal neurons through a PKA/ DARPP-32/PP1 signaling cascade. J Neurophysiol 83:2996-3004.

Galarraga E, Hernandez-Lopez S, Reyes A, Miranda I, Bermudez-Rattoni F, Vichis C, Bargas J (1999) Cholinergic modulation of neostriatal output: a functional antagonism between different types of muscarinic receptors. J Neurosci 19:3629-3638.

Guiramand J, Montmayeur JP, Ceraline J, Bhatia M, Borrelli E (1995) Alternative splicing of the dopamine D2 receptor directs specificity of coupling to G-proteins. J Biol Chem 270:7354-7358.

Hernandez-Lopez S, Tkatch T, Perez-Garci E, Galarraga E, Bargas J, Hamm H, Surmeier DJ (2000) D2 dopamine receptors in striatal medium spiny neurons reduce L-type $\mathrm{Ca}^{2+}$ currents and excitability via a novel PLC $\beta 1$ $\mathrm{IP}_{3}$-calcineurin-signaling cascade. J Neurosci 20:8987-8995.

Hollon TR, Bek MJ, Lachowicz JE, Ariano MA, Mezey E, Ramachandran R, Wersinger SR, Soares-da-Silva P, Liu ZF, Grinberg A, Drago J, Young III WS, Westphal H, Jose PA, Sibley DR (2002) Mice lacking D5 dopamine receptors have increased sympathetic tone and are hypertensive. J Neurosci 22:10801-10810.

Holmes A, Hollon TR, Gleason TC, Liu Z, Dreiling J, Sibley DR, Crawley JN (2001) Behavioral characterization of dopamine D5 receptor null mutant mice. Behav Neurosci 115:1129-1144.

Hsu KS, Huang CC, Yang CH, Gean PW (1995) Presynaptic D2 dopaminergic receptors mediate inhibition of excitatory synaptic transmission in rat neostriatum. Brain Res 690:264-268.

Hyman SE, Malenka RC (2001) Addiction and the brain: the neurobiology of compulsion and its persistence. Nat Rev Neurosci 2:695-703.

Jaeger D, Kita H, Wilson CJ (1994) Surround inhibition among projection neurons is weak or nonexistent in the rat neostriatum. J Neurophysiol 72:2555-2558.

Jiang Z-C, North RA (1991) Membrane properties and synaptic responses of rat striatal neurones in vitro. J Physiol (Lond) 443:533-553.

Kawaguchi Y (1992) Large aspiny cells in the matrix of the rat neostriatum 
in vitro: physiological identification, relation to the compartments and excitatory postsynaptic currents. J Neurophysiol 67:1669-1682.

Kawaguchi Y (1993) Physiological, morphological, and histochemical characterization of three classes of interneurons in rat neostriatum. J Neurosci 13:4908-4923.

Kawaguchi Y, Wilson CJ, Augood SJ, Emson PC (1995) Striatal interneurones: chemical, physiological and morphological characterization. Trends Neurosci 18:527-535.

Kerr JND, Wickens JR (2001) Dopamine D-1/D-5 receptor activation is required for long-term potentiation in the rat neostriatum in vitro. J Neurophysiol 85:117-124.

Khan ZU, Gutierrez A, Martin R, Penafiel A, Rivera A, de la Calle A (2000) Dopamine D5 receptors of rat and human brain. Neuroscience 100:689-699.

Kita H (1993) GABAergic circuits of the striatum. Prog Brain Res 99:51-72.

Koos T, Tepper JM (1999) Inhibitory control of neostriatal projection neurons by GABAergic interneurons. Nat Neurosci 2:467-472.

Koos T, Tepper JM (2002) Dual cholinergic control of fast-spiking interneurons in the neostriatum. J Neurosci 22:529-535.

Lewis DA, Lieberman JA (2000) Catching up on schizophrenia: natural history and neurobiology. Neuron 28:325-334.

Lin YJ, Greif GJ, Freedman JE (1996) Permeation and block of dopaminemodulated potassium channels on rat striatal neurons by cesium and barium ions. J Neurophysiol 76:1413-1422.

Luedtke RR, Griffin SA, Conroy SS, Jin X, Pinto A, Sesack SR (1999) Immunoblot and immunohistochemical comparison of murine monoclonal antibodies specific for the rat $\mathrm{D} 1 \mathrm{a}$ and $\mathrm{D} 1 \mathrm{~b}$ dopamine receptor subtypes. J Neuroimmunol 101:170-187.

Momiyama T, Koga E (2001) Dopamine D(2)-like receptors selectively block $\mathrm{N}$-type $\mathrm{Ca}(2+)$ channels to reduce GABA release onto rat striatal cholinergic interneurones. J Physiol (Lond) 533:479-492.

Nicola SM, Surmeier J, Malenka RC (2000) Dopaminergic modulation of neuronal excitability in the striatum and nucleus accumbens. Annu Rev Neurosci 23:185-215.

Obeso JA, Rodríguez-Oroz MC, Rodríguez M, Lanciego JL, Artieda J, Gonzalo N, Olanow CW (2000) Pathophysiology of the basal ganglia in Parkinson's disease. Trends Neurosci 23:S8-S19.

Pisani A, Bonsi P, Centonze D, Calabresi P, Bernardi G (2000) Activation of D2-like dopamine receptors reduces synaptic inputs to striatal cholinergic interneurons. J Neurosci 20:RC69(1-6).

Plenz D, Kitai ST (1998) Up and down states in striatal medium spiny neurons simultaneously recorded with spontaneous activity in fast-spiking interneurons studied in cortex-striatum-substantia nigra organotypic cultures. J Neurosci 18:266-283.

Rivera A, Cuellar B, Giron FJ, Grandy DK, de la Calle A, Moratalla R (2002a) Dopamine D4 receptors are heterogeneously distributed in the striosomes/matrix compartments of the striatum. J Neurochem 80:219-229.

Rivera A, Alberti I, Martin AB, Narvaez JA, de la Calle A, Moratalla R (2002b) Molecular phenotype of rat striatal neurons expressing the dopamine D5 receptor subtype. Eur J Neurosci 16:2049-2058.

Schiffmann SN, Lledo PM, Vincent JD (1995) Dopamine D1 receptor mod- ulates the voltage-gated sodium current in rat striatal neurons through a protein kinase A. J Physiol (Lond) 483:95-107.

Sunahara RK, Guan HC, O’Dowd BF, Seeman P, Laurier LG, Ng G, George SR, Torchia J, Van Tol HH, Niznik HB (1991) Cloning of the gene for a human dopamine D5 receptor with higher affinity for dopamine than D1. Nature 350:614-619.

Surmeier DJ, Bargas J, Hemmings Jr HC, Nairn AC, Greengard P (1995) Modulation of calcium currents by a D1 dopaminergic protein kinase/ phosphatase cascade in rat neostriatal neurons. Neuron 14:385-397.

Surmeier DJ, Song WJ, Yan Z (1996) Coordinated expression of dopamine receptors in neostriatal medium spiny neurons. J Neurosci 16:6579-6591.

Tang K-C, Low MJ, Grandy DK, Lovinger DM (2001) Dopaminedependent synaptic plasticity in striatum during in vivo development. Proc Natl Acad Sci USA 98:1255-1260.

Tiberi M, Jarvie KR, Silvia C, Falardeau P, Gingrich JA, Godinot N, Bertrand L, Yang-Feng TL, Fremeau Jr RT, Caron MG (1991) Cloning, molecular characterization, and chromosomal assignment of a gene encoding a second D1 dopamine receptor subtype: differential expression pattern in rat brain compared with the D1A receptor. Proc Natl Acad Sci USA 88:7491-7495.

Tunstall MJ, Oorschot DE, Kean A, Wickens JR (2002) Inhibitory interactions between spiny projection neurons in the rat striatum. J Neurophysiol 88:1263-1269.

Usiello A, Baik J-H, Rouge-Pont F, Picetti R, Dierich A, LeMeur M, Piazza PV, Borrelli E (2000) Distinct functions of the two isoforms of dopamine D2 receptors. Nature 408:199-202.

Wang Y, Xu R, Sasaoka T, Tonegawa S, Kung M-P, Sankoorikal E-B (2000) Dopamine D2 long receptor-deficient mice display alterations in striatum-dependent functions. J Neurosci 20:8305-8314.

Wickens JR, Kotter R, Alexander ME (1995) Effects of local connectivity on striatal function: stimulation and analysis of a model. Synapse 20:281-298.

Wilson CJ, Groves PM (1980) Fine structure and synaptic connections of the common spiny neuron of the rat neostriatum: a study employing intracellular injection of horseradish peroxidase. J Comp Neurol 194:599-615.

Xu M, Moratalla R, Gold LH, Hiroi N, Koob GF, Graybiel AM, Tonegawa S (1994) Dopamine D1 receptor mutant mice are deficient in striatal expression of dynorphin and in dopamine-mediated behavioral responses. Cell 79:729-742.

Yan Z, Surmeier DJ (1997) D5 dopamine receptors enhance $\mathrm{Zn}^{2+}$-sensitive GABA(A) currents in striatal cholinergic interneurons through a PKA/ PP1 cascade. Neuron 19:1115-1126.

Yan Z, Song WJ, Surmeier J (1997) D2 dopamine receptors reduce N-type $\mathrm{Ca}^{2+}$ currents in rat neostriatal cholinergic interneurons through a membrane-delimited, protein-kinase-C-insensitive pathway. J Neurophysiol 77:1003-1015.

Yung KK, Smith AD, Levey AI, Bolam JP (1996) Synaptic connections between spiny neurons of the direct and indirect pathways in the neostriatum of the rat: evidence from dopamine receptor and neuropeptide immunostaining. Eur J Neurosci 8:861-869. 